\title{
Ethanol-induced Germ Tube Formation in Candida albicans
}

\author{
By JORDAN H. POLLACK AND TADAYO HASHIMOTO* \\ Department of Microbiology, Loyola University of Chicago, Stritch School of Medicine, \\ 2160 South First Avenue, Maywood, IL 60153, USA
}

(Received 7 May 1985; revised 16 July 1985)

\begin{abstract}
Ethanol is the first reported compound which can induce germ tube formation in Candida albicans without the addition of any nitrogen-containing nutrients. Conditions controlling induction of germ tubes in C. albicans by ethanol were investigated. Ethanol $(17 \cdot 1 \mathrm{mM})$ in buffered salts solution containing sodium bicarbonate induced 70 to $80 \%$ of yeast phase cells of C. albicans to form germ tubes. Germ tubes could be induced by ethanol ( 0.08 to $340 \mathrm{~mm})$ at temperatures ranging from 29 to $41^{\circ} \mathrm{C}$ (optimum $37^{\circ} \mathrm{C}$ ) and at $\mathrm{pH}$ values ranging from 3.0 to 8.0 (optimum 5.75). The germ tubes averaged $11 \mu \mathrm{m}$ in length after $6 \mathrm{~h}$ at $37^{\circ} \mathrm{C}$. The percentage of cells forming germ tubes decreased as the concentration of cells in the induction solution was increased above $4 \times 10^{5}$ cells ml-1. Germ tubes first appeared 45 to $60 \mathrm{~min}$ after continuous exposure to ethanol at $37^{\circ} \mathrm{C}$ and all cells which formed germ tubes did so by $2 \mathrm{~h}$. Germ tube length decreased as the $\mathrm{pH}$ was increased but was independent of the concentration of ethanol. Oxygen was required for germ tube formation. In addition to ethanol, 1-propanol, 2-propanol, 1-butanol and acetic acid could induce germ tube formation, whereas methanol could not. These results indicate that the cells must mobilize their endogenous nitrogen and probably carbohydrate reserves in order to initiate formation of germ tubes. The evidence is inconclusive as to whether ethanol itself must be metabolized for germ tube induction to occur, although it is not thought to act by a nonspecific interaction with the cell membrane.
\end{abstract}

\section{INTRODUCTION}

Ethanol has been reported to induce a number of morphological changes in fungi. These changes range from the production of rhizomorphs, instead of mycelia, in Armillaria mellea (Weinhold, 1963), germination of macrospores of Fusarium solani (Cochrane et al., 1963; Paz et al., 1984), formation of Saccharomyces cerevisiae ascospores (Miller \& Halpern, 1956), branching of germ tubes of Peronospora parasitica (McMeekin, 1981) and germ tube formation by Aureobasidium pullulans (Sevilla et al., 1983) and Candida tropicalis (Tani et al., 1979). There has been only one previous report of Candida albicans forming germ tubes when the growth medium was supplemented with ethanol (Reynouard et al., 1979). However, filamentation did not appear until the tenth day of exposure, at which time germ tubes were also reported in the control sample. Land et al. (1975) found ethanol could not replace glucose in a proline/glucose germ tube induction medium. Chiew et al. (1982) reported that $4 \%$ ethanol inhibited germ tube formation, while Bell \& Chaffin (1983) reported that growth in medium containing even $0.1 \%$ ethanol as the carbon source, before induction by the medium of Lee et al. (1975), inhibited germ tube formation in C. albicans.

Previous findings that certain $L$-amino acids such as proline, glutamine and arginine or amino sugars such as $\mathrm{N}$-acetylglucosamine (GlcNAc) (Odds, 1979) or 'gratuituous' inducers such as $\mathrm{N}$ acetylmannosamine or GlcNAc coupled to agarose (Sullivan \& Shepherd, 1982; Shepherd \& Sullivan, 1983) seemed to indicate that the action of an amino- or imino-containing compound

Abbreviations: ADH, alcohol dehydrogenase; DMEM, Dulbecco's modified Eagle medium. 
was necessary for induction of germ tubes in C. albicans. We have reported (Pollack \& Hashimoto, 1984) that millimolar concentrations of ethanol, initially identified as a minor contaminant of some commercial buffer preparations, are capable of inducing germ tube formation in C. albicans. This implies that not only does the inducer not have to be an amino- or imino-containing compound, but also that competent $C$. albicans cells do not require any exogenous nitrogen sources for initiating germ tube formation. In previous reports of maltose or starch inducing germ tube formation, the effect was observed only in the presence of $\left(\mathrm{NH}_{4}\right)_{2} \mathrm{SO}_{4}$ (Shepherd \& Sullivan, 1976) or neopeptone (Chattaway et al., 1968). Because of the potential usefulness of this system in investigating nitrogen turnover associated with the early phase of dimorphic conversion, we have further examined the conditions that critically affect ethanolinduced germ tube formation in C. albicans.

\section{METHODS}

Organism. A clinically isolated strain of C. albicans (ATCC 58716, serotype A, formerly LUMC 101) was used. This strain was previously shown to form germ tubes when induced by ethanol (Pollack \& Hashimoto, 1984). In some instances $C$. albicans ATCC 10261 was also used for comparison. Cells were maintained on Sabouraud dextrose agar (Difco) at $20^{\circ} \mathrm{C}$.

Preparation of yeast phase cells. Yeast phase cells grown on Sabouraud dextrose agar for $24 \mathrm{~h}$ at $37^{\circ} \mathrm{C}$ were collected and washed with glass distilled, deionized water 10 times by vacuum filtration on a Millipore filter $(0.45 \mu \mathrm{m}$ pore size $)$ using a Millipore filtration apparatus. To ensure complete washing, the cells were resuspended in the water by repeated suction and forcible ejection through a Pasteur pipette between each washing. The washed cells were then resuspended in distilled water and used for inoculating the induction solution.

Induction of germ tube formation. C. albicans yeast phase cells $\left(2.5\right.$ to $7.5 \times 10^{5} \mathrm{cells}^{-1}$, determined turbidimetrically, final concentration) were inoculated into a buffered salts solution containing the following $\left(\mathrm{mg} \mathrm{l}^{-1}\right): \mathrm{FeSO}_{4}, 0 \cdot 1 ; \mathrm{KCl}, 400 ; \mathrm{MgSO}_{4} .7 \mathrm{H}_{2} \mathrm{O}, 200 ; \mathrm{NaH}_{2} \mathrm{PO}_{4} . \mathrm{H}_{2} \mathrm{O}, 125 ; \mathrm{NaCl}, 6400 ;$ and $\mathrm{NaHCO}_{3}, 750$. Unless otherwise indicated, Tris/maleate buffer (Sigma; $0.05 \mathrm{M}, \mathrm{pH} 5.75$ ) was used. The absence of ethanol from the buffer was confirmed by gas chromatography (Perkin-Elmer gas chromatograph, model 910), as previously described (Pollack \& Hashimoto, 1984). Unless otherwise indicated, the ethanol concentration added to the buffered salts solution was $0.1 \%(\mathrm{v} / \mathrm{v} ; 17.1 \mathrm{mM})$. Dulbecco's Modified Eagle Medium (DMEM; Gibco) was used for induction in some experiments for comparative purposes after adjusting the $\mathrm{pH}$ value to 5.75 by dropwise addition of $0 \cdot 1 \mathrm{M}-\mathrm{HCl}$, followed by vigorous shaking to remove $\mathrm{CO}_{2}$. The cells were incubated in the induction solution (final volume $0.5 \mathrm{ml}$ ) for $4 \mathrm{~h}$ at $37^{\circ} \mathrm{C}$.

The extent of hyphal (germ tube) formation was routinely determined by counting 100 to 200 cells in each sample under a phase-contrast microscope. Germ tubc length was measured with a calibrated eyepiece micrometer. Photomicrographs were taken with a Nikon M-35S camera attached to the microscope, using panchromatic film (Plus-X; Eastman Kodak).

Oxygen requirement for induction of germ tubes. To determine whether oxygen was required for germ tube formation in C. albicans cells induced by ethanol, a GasPak anaerobic system (BBL) was used. To ensure that the cells were not inoculated into the induction solution before highly anaerobic conditions had been attained, the cell suspension was kept in a side arm attached to the test tube containing the induction solution. The tube was then secured in a rack placed in a GasPak anaerobic jar (BBL) which was then activated. After attainment of highly anaerobic conditions in the jar the cells in the side arm were allowed to mix with the induction medium and incubated at $37^{\circ} \mathrm{C}$ for $4 \mathrm{~h}$.

\section{RESULTS}

\section{Induction of germ tubes by ethanol}

When 24-h-old yeast cells of C. albicans were incubated in buffered salts solution containing $17 \cdot 1 \mathrm{~mm}$-ethanol at $37^{\circ} \mathrm{C}, 70$ to $80 \%$ of the inoculated cells formed germ tubes in $4 \mathrm{~h}$ (Table 1 ). Virtually no cells formed germ tubes in the absence of ethanol. All germ tubes formed in response to ethanol induction appeared somewhat thinner than those produced in rich media such as serum or DMEM (Fig. 1). The presence of bicarbonate in the incubation medium was essential for ethanol to induce these cells to form germ tubes (Table 1). Other common salts of magnesium, manganese, calcium, iron and sodium were not required for germ tube formation.

Although most experiments reported in this paper were done using Tris/maleate buffer, similar results were obtained when Tris/maleate was replaced by other common buffers such as sodium phosphate, citrate/phosphate, succinate, $t$-aconitate, HEPES, MES, MOPS and PIPES. 

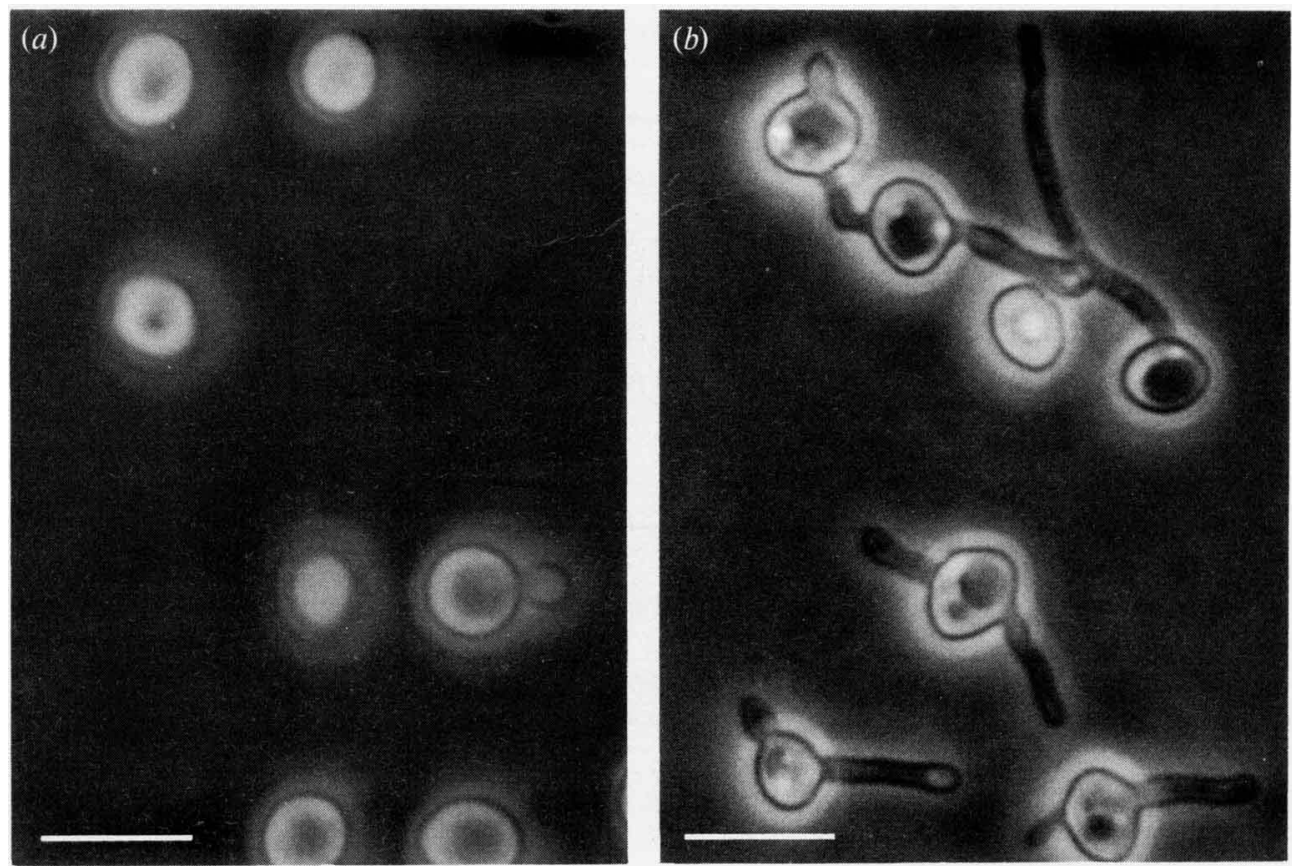

Fig. 1. Phase-contrast micrographs of (a) C. albicans yeast cells grown for $24 \mathrm{~h}$ on Sabouraud dextrose agar, and $(b)$ germ-tube-forming cells after $4 \mathrm{~h}$ induction by ethanol $(0 \cdot 1 \%)$ at $37^{\circ} \mathrm{C}$. Bars, $10 \mu \mathrm{m}$.

\section{Table 1. Salt requirements for induction of germ tubes by ethanol}

Values are the means of five independent experiments \pm SEM. Composition of the buffered salts is detailed in Methods.

\section{Induction solution}

Buffered salts $+0 \cdot 1 \%$ ethanol

Buffered salts $-\mathrm{HCO}_{3}^{-}+0 \cdot 1 \%$ ethanol

Buffer $+\mathrm{HCO}_{3}^{-}+0.1 \%$ ethanol

Buffer $+0.1 \%$ ethanol

Buffered salts

DMEM (control)
Percentage of cells forming germ tubes

$$
\begin{array}{r}
77.6 \pm 4 \cdot 1 \\
23.0 \pm 2.4 \\
74.2 \pm 6.1 \\
17.4 \pm 6.8 \\
1.9 \pm 0.8
\end{array}
$$$$
100
$$

Under all conditions tested, ethanol did not induce germ tube formation in $100 \%$ of cells. However, essentially all of the cells formed germ tubes when incubated in rich media such as DMEM (Table 1). Ethanol-induced germ tube formation in C. albicans was not limited to strain ATCC 58716: approximately $80 \%$ of $C$. albicans ATCC 10261 also formed germ tubes when induced by $0 \cdot 1 \%$ ethanol under similar conditions.

\section{Optimal conditions for ethanol-induced germ tube formation}

The induction of germ tubes in C. albicans by ethanol was critically affected by a number of parameters. Optimal germ tube formation (approximately $80 \%$ ) occurred at the lowest concentration of cells tested $\left(4 \times 10^{5}\right.$ cells $\left.\mathrm{ml}^{-1}\right)$. The percentage of cells forming germ tubes decreased proportionately as the cell concentration increased, so that almost no cells formed germ tubes when the cell concentration was greater than $4.5 \times 10^{6}$ cells ml $^{-1}$. The optimal temperature for germ tube formation was $37^{\circ} \mathrm{C}$; however, approximately $20 \%$ of the cells formed germ tubes at either $29^{\circ} \mathrm{C}$ or $42^{\circ} \mathrm{C}$. No cells formed germ tubes below $28^{\circ} \mathrm{C}$ or above 


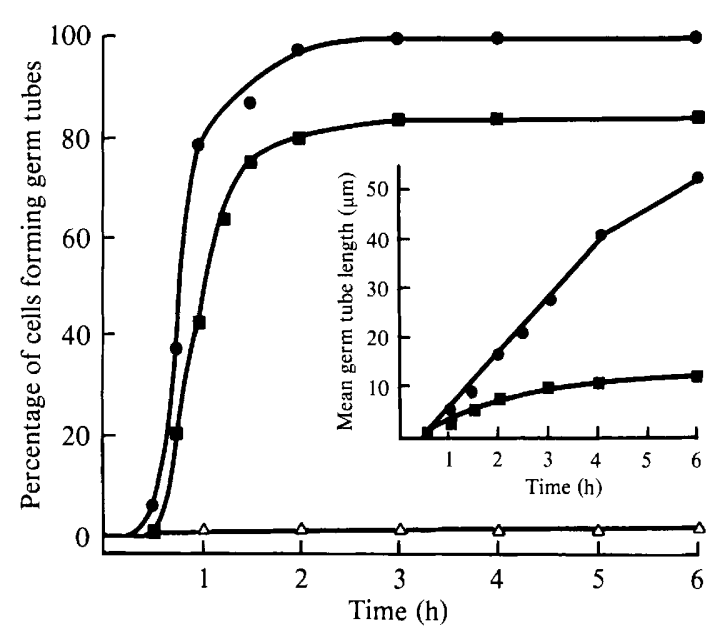

Fig. 2. Kinetics of germ tube formation. Cells were induced to form germ tubes at pH 5.75 and $37^{\circ} \mathrm{C}$ either by DMEM $(\mathbf{O})$ or by $0.1 \%$ ethanol in buffered salts solution $(\boldsymbol{\square})$. No germ tubes were formed in buffered salts solution in the absence of ethanol $(\triangle)$. The mean length of the germ tubes formed at each interval is indicated in the inset.

$43^{\circ} \mathrm{C}$. Maximal germ tube formation occurred at a $\mathrm{pH}$ range of 5.0 to 5.75 , with $40 \%$ of the cells forming germ tubes at either $\mathrm{pH} 3.0$ or 7.5 . Essentially no germ tubes formed below $\mathrm{pH} 2.5$ or above $\mathrm{pH} 8.5$. A wide range of concentrations of ethanol, from $0.34 \mathrm{~mm}$ to $170 \mathrm{~mm}$, induced optimal or near optimal germ tube formation. Even ethanol concentrations of $0.09 \mathrm{~mm}$ or $340 \mathrm{~mm}$ induced approximately $20 \%$ of the cells to form germ tubes. However, no germ tubes were induced at ethanol concentrations above $680 \mathrm{~mm}$ or below $0.03 \mathrm{~mm}$. Since $C$. albicans can grow anaerobically, we tested the ability of ethanol to induce hyphal growth under strict anaerobic conditions. No germ tubes were formed under strict anaerobiosis, with ethanol or any of the other inducers tested.

\section{Kinetics of ethanol-induced germ tube formation}

Discernible germ tubes first appeared approximately 45 to $60 \mathrm{~min}$ after exposure to ethanol. The initial rate of germ tube formation induced by ethanol was slightly slower than that induced by DMEM. The maximum percentage of cells forming germ tubes was attained by $2 \mathrm{~h}$ with either ethanol or DMEM (Fig. 2).

The germ tube lengths for ethanol-induced cells drastically decreased as the $\mathrm{pH}$ of the medium was increased above 6.0 . At $\mathrm{pH} 5.75$ the longest germ tubes were approximately $30 \mu \mathrm{m}$ long, the mean length being about $11 \mu \mathrm{m}$ after $6 \mathrm{~h}$. However, at $\mathrm{pH} 7 \cdot 2$ the longest germ tubes were only 10 to $12 \mu \mathrm{m}$ long, the mean being only $4 \mu \mathrm{m}$ after $6 \mathrm{~h}$. There were no significant differences in the mean germ tube length when the concentration of ethanol was increased from $0.001 \%(0.17 \mathrm{mM})$ to $1.0 \%(171 \mathrm{~mm})$ (data not shown).

\section{Other compounds capable of hyphal induction}

Of all the alcohols tested only 1-propanol, 2-propanol and 1-butanol were capable of inducing germ tubes. None of these alcohols was able to induce as high a percentage of cells to form germ tubes as ethanol (Table 2). Methanol, 2-butanol, 3-butanol, 1-pentanol, 2-pentanol, phenylethyl alcohol, acetone, methylethyl ketone, dimethyl sulphoxide, polyethylene glycol 400 and 6000 , Triton-X 100 and acetaldehyde could not induce germ tube formation in strain ATCC 58716 of C. albicans. However, $0 \cdot 1 \%$ acetic acid was also capable of inducing $50 \%$ of the cells to form germ tubes. 
Table 2. Induction of germ tubes by higher alcohols and related compounds

\begin{tabular}{|c|c|c|c|c|}
\hline \multirow[b]{2}{*}{ Compound } & \multicolumn{4}{|c|}{$\begin{array}{l}\text { Percentage of cells forming germ tubes } \\
\text { at an inducer concn }(\%, v / v) \text { of: }\end{array}$} \\
\hline & 0.5 & $0 \cdot 1$ & 0.01 & 0.001 \\
\hline 1-Propanol & $20 \cdot 2 \pm 7 \cdot 1$ & $51 \cdot 2 \pm 3 \cdot 6$ & $48 \cdot 2 \pm 5 \cdot 0$ & $22 \cdot 8 \pm 4.5$ \\
\hline 2-Propanol & $36.5 \pm 9 \cdot 1$ & $49 \cdot 2 \pm 4 \cdot 0$ & $43.5 \pm 7 \cdot 1$ & $8.0 \pm 4.4$ \\
\hline 1-Butanol & $3.5 \pm 0.9$ & $23.0 \pm 5.4$ & $24.8 \pm 6.5$ & $10.2 \pm 2.8$ \\
\hline Acetic acid & 0 & $49 \cdot 0 \pm 3 \cdot 0^{*}$ & $20.5 \pm 18.5^{*}$ & 0 \\
\hline
\end{tabular}

Table 3. Germ tube formation in the presence of pyrazole and allyl alcohol

\begin{abstract}
Allyl alcohol and/or pyrazole were added to the buffered salts solution described in Methods and containing either ethanol $(17.1 \mathrm{mM})$ or GlcNAc $(4 \mathrm{~mm})$ as the inducer. The final volume in each tube was $0.625 \mathrm{ml}$.
\end{abstract}

Inhibitor

None

Allyl alcohol (0.5 mM)

Pyrazole (10 mM)

Pyrazole (5 mM)

Pyrazole (1 mM)

Pyrazole $(0.5 \mathrm{~mm})$

Allyl alcohol (0.5 mM) + pyrazole ( $0.5 \mathrm{~mm})$

Allyl alcohol $(0.5 \mathrm{~mm})+$ pyrazole $(1 \mathrm{~mm})$

Allyl alcohol $(5 \mathrm{mM})+$ pyrazole $(5 \mathrm{~mm})$

Allyl alcohol $(5 \mathrm{~mm})+$ pyrazole $(10 \mathrm{~mm})$

Allyl alcohol $(50 \mathrm{~mm})+$ pyrazole $(20 \mathrm{~mm})$

Allyl alcohol $(50 \mathrm{mM})+$ pyrazole $(50 \mathrm{~mm})$
Percentage of cells forming germ tubes when induced by:

$\begin{array}{rr}\text { Ethanol } & \text { GlcNAc } \\ 77 & 100 \\ 0 & 0 \\ 11 & 100 \\ 38 & 100 \\ 65 & 100 \\ 71 & 100 \\ 0 & 35 \\ 3 & 100 \\ 0 & 13 \\ 0 & 88 \\ 0 & 0 \\ 0 & 62\end{array}$

\title{
Alcohol dehydrogenase involvement in ethanol-induced germ tube formation
}

To determine whether metabolism of ethanol by alcohol dehydrogenase (ADH) is necessary for germ tube formation, we tested the effect of adding allyl alcohol and pyrazole, an inhibitor of yeast ADH (Reynier, 1969). Allyl alcohol is converted to the lethal compound acrolein, in the presence of ADH. However, the conversion of allyl alcohol to acrolein is inhibited by pyrazole, allowing the cells to grow (Paz et al., 1984). Allyl alcohol $(0.05 \mathrm{~mm}$ to $50 \mathrm{~mm})$ and pyrazole $(0.5 \mathrm{~mm}$ to $50 \mathrm{mM})$ were added to the induction solution $(0.625 \mathrm{ml}$, final volume $)$ containing either ethanol $(0.1 \%)$ or GlcNAc $(4 \mathrm{mM})$ as the inducer. The percentage of cells forming germ tubes was assessed after $6 \mathrm{~h}$.

The ability of pyrazole to inhibit the lethal action of allyl alcohol could be demonstrated only if C. albicans was induced to form germ tubes by GlcNAc. This ability was dependent on the concentration of both pyrazole and allyl alcohol (Table 3). As the concentration of allyl alcohol in the induction solution was increased, a similar increase in the concentration of pyrazole was required to overcome the lethal effects. In all instances where a lethal concentration of allyl alcohol $(0.5 \mathrm{~mm})$ was added, ethanol could not induce germ tube formation regardless of the concentration of pyrazole. Indeed pyrazole itself was inhibitory to ethanol-induced, but not to GlcNAc-induced germ tube formation, at a concentration greater than $5 \mathrm{~mm}$. However, pyrazole alone, at $1 \mathrm{mM}$, a concentration sufficient to overcome the lethal effects of $0.5 \mathrm{mM}$-allyl alcohol in the GlcNAc-inducing system, did not significantly affect the germ tube-inducing capacity of ethanol. Thus, while germ tube induction by ethanol may be possible even when $\mathrm{ADH}$ is inhibited, these results are not conclusive. 


\section{DISCUSSION}

One of the most perplexing aspects of germ tube induction by ethanol is that, under the optimal conditions found, ethanol can induce at most $85 \%$ of the cells to form germ tubes. On the other hand GlcNAc, L-proline or DMEM consistently induce essentially all of the cells to form germ tubes. This effect may be due to each cell in the population being required to arrive at some critical point in the cell cycle in order for hyphal formation to ensue. Although a number of investigators have shown that under given conditions cells from all growth phases are capable of being induced (Mattia \& Cassone, 1979; Ahrens et al., 1983; Soll \& Herman, 1983), it is still possible that their conditions actually bring the cells to a critical cell cycle point when the cells are 'pluripotent'. Thus, while other inducers are rich enough nutrients to bring every cell in an asynchronous population to this critical point, ethanol may be too poor a nutrient source to accomplish this. Hence, a certain percentage of cells would remain ungerminated.

The possible lack of sufficient storage reserves in each cell of the population, or of the ability to utilize them, may also account for the fact that less than $100 \%$ of the cells formed germ tubes. Both trehalase and glucoamylase are induced by ethanol in Saccharomyces cerevisiae (Panek, 1962; Rambeck \& Simon, 1972) and mobilization of glycogen does seem to correlate with germ tube formation in C. albicans (Sullivan et al., 1983). Wall lytic enzymes may also be required for germ tube formation (Ram et al., 1984; Sullivan et al., 1984). Recent reports on proteases secreted by C. albicans (MacDonald, 1984; Samaranayake et al., 1984; Rüchel, 1984) have all emphasized their possible roles in the pathogenicity of $C$. albicans, but have not considered the possibility that the breakdown of cytoplasmic materials or wall glycoproteins may also be integrally involved in germ tube formation. We have yet to show a relationship between ethanol and mobilization of carbohydrate or nitrogen reserves in $C$. albicans, yet it would seem very likely that such mobilization is necessary for germ tube formation to occur. Carbohydrate reserves probably are necessary to supplement the small concentration of ethanol required to induce germ tube formation, and it is certain that all nitrogen must be obtained endotrophically as there is no exogenous nitrogen in the induction solution. Thus, differences in a certain percentage of cells in a population able to respond to ethanol may be attributed to differences in their endogenous reserves.

The basis of the requirement of bicarbonate for the effective induction of germ tubes by ethanol (Table 1) is not understood, especially since this requirement was eliminated if the cells were starved by incubating them in water at $20^{\circ} \mathrm{C}$ for $24 \mathrm{~h}$ before induction (unpublished observations). There is a possibility that bicarbonate may be required for the metabolism of ethanol, or that it may increase the permeability of the cell membrane to ethanol, as has been suggested in the case of dimorphism in Mucor (Stewart \& Rodgers, 1983). It does seem unlikely, though, that bicarbonate is an initiator of dimorphism in C. albicans (Mardon et al., 1969) since it is not universally required.

While the $\mathrm{pH}$ values at which ethanol induced germ tube formation were considerably below those reported for other systems (Evans et al., 1975; Simonetti et al., 1974; Mitchell \& Soll, 1979), replacing ethanol with GlcNAc, proline or DMEM in our system gave similar results (unpublished data). Thus it would seem that the composition of the induction medium plays a major role in the sensitivity to $\mathrm{pH}$.

The recent evidence that a metabolizable inducer is not required for germ tube induction (Sullivan \& Shepherd, 1982; Shepherd \& Sullivan, 1983), prompted us to check if ethanol metabolism is required for germ tube induction. Our attempts to clarify this issue using pyrazole, an inhibitor of yeast ADH (Reynier, 1969), were inconclusive. A concentration of pyrazole (1 mM) capable of inhibiting the lethal action of a low concentration of allyl alcohol, and presumably of inhibiting ADH, was found, suggesting the possibility that ethanol metabolism via $\mathrm{ADH}$ is not required. However, this inhibitory action of pyrazole could not be demonstrated in the presence of allyl alcohol in an ethanol-induced system, for unknown reasons. It is possible that sufficient $\mathrm{ADH}$ remained active in the presence of $1 \mathrm{mM}$-pyrazole to metabolize whatever ethanol was necessary for germ tube formation. It is not possible to argue that higher concentrations of pyrazole were inhibitory because they more severely inhibited ADH, since imidazole, an isomer of pyrazole which does not counteract the effects of allyl alcohol, also 
inhibits germ tube induction (data not shown), presumably by a mechanism other than inhibition of $\mathrm{ADH}$. However, even if $\mathrm{ADH}$ is not required for ethanol-induced germ tube formation, this only eliminates one route for ethanol metabolism. Alcohol can also be metabolized oxidatively by a microsomal ethanol oxidizing system in rats (Lieber \& DeCarli, 1968), and non-oxidatively by esterification with fatty acids (Lange, 1982). Thus we cannot yet exclude the possibility that ethanol must be metabolized for germ tube induction to occur. The fact that increasing concentrations of ethanol did not result in significantly longer germ tubes might be explained by the fact that the endogenous nitrogen reserves limited the ultimate germ tube length.

Although propanol and butanol could also induce germ tube formation, the results would seem to indicate that the effect of ethanol is not due to a non-specific interaction with the cell membrane, as has been suggested for ethanol-induced dimorphism in Aureobasidium pullulans (Sevilla et al., 1983), since methanol and other membrane-disturbing compounds were completely ineffective in inducing germ tube formation in C. albicans. As it is possible that methanol cannot be metabolized by $C$. albicans and thus germ tube induction would not be recognized, we did attempt to induce germ tubes with methanol in combination with glucose and other sugars and amino acids. No germ tubes were formed unless methanol was combined with an amino acid which could induce germ tubes by itself (data not shown). Thus, it appears that the ethanol effect in $C$. albicans is more specific than that thought to occur in $A$. pullulans.

\section{REFERENCES}

Ahrens, J. C., Price, M. R., Daneo-Moore, L. \& BUCKLEY, H. R. (1983). Effects of culture density on the kinetics of germ tube formation in Candida albicans. Journal of General Microbiology 129, 30013006.

Bell, W. M. \& Chaffin, W. L. (1983). Effect of yeast growth conditions on yeast-mycelial transition in Candida albicans. Mycopathologia 84, 41-44.

Chattaway, F. W., Holmes, M. R. \& Barlow, A. J. E. (1968). Cell wall composition of the mycelial and blastospore forms of Candida albicans. Journal of General Microbiology 51, 367-376.

Chiew, Y. Y., Sullivan, P. A. \& Shepherd, M. G. (1982). The effects of ergosterol and alcohols on germ-tube formation and chitin synthase in Candida albicans. Canadian Journal of Biochemistry $\mathbf{6 0}$, 15-20.

Cochrane, J. C., Cochrane, V. W., Simon, F. G. \& SPAETH, J. (1963). Spore germination and carbon metabolism in Fusarium solani. I. Requirements for spore germination. Phytopathology 53, 1155-1160.

Evans, E. G. V., Odds, F. C., Richardson, M. D \& Holland, K. T. (1975). Optimum conditions for initiation of filamentation in Candida albicans. Canadian Journal of Microbiology 21, 338-342.

Land, G. A., McDonald, W. C., STJernholm, R. L. \& Friedman, L. (1975). Factors affecting filamentation in Candida albicans: changes in respiratory activity of Candida albicans during filamentation. Infection and Immunity 12, 119-127.

LANGE, L. G. (1982). Nonoxidative ethanol metabolism: formation of fatty acid ethyl esters by cholesterol esterase. Proceedings of the National Academy of Sciences of the United States of America 79, 3954-3957.

Lee, K. L., Buckley, H. R. \& Campbell, C. C. (1975). An amino acid liquid synthetic medium for the development of mycelial and yeast forms of Candida albicans. Sabouraudia 13, 148-153.

Lieber, C. S. \& DeCARLI, L. M. (1968). Ethanol oxidation by hepatic microsomes: adaptive increase after ethanol feeding. Science 162, 917-918.

MACDONALD, F. (1984). Secretion of inducible proteinase by pathogenic Candida species. Sabouraudia 22 , $79-82$.

MCMEEKIN, D. (1981). Initiation of branching in the germ tubes of Peronospora parasitica by alcohol. Mycologia 73, 252-262.

Mardon, D., Balish, E. \& Phillips, A. W. (1969). Control of dimorphism in a biochemical variant of Candida albicans. Journal of Bacteriology 100, 701707.

Mattia, E. \& Cassone, A. (1979). Inducibility of germtube formation in Candida albicans at different phases of yeast growth. Journal of General Microbiology 113, 439-442.

Miller, J. J. \& Halpern, C. (1956). The metabolism of yeast sporulation. 1. Effect of certain metabolites and inhibitors. Canadian Journal of Microbiology $\mathbf{2}$, 519-537.

Mitchell, L. H. \& Soll, D. R. (1979). Commitment to germ tube or bud formation during release from stationary phase in Candida albicans. Experimental Cell Research 120, 167-179.

OdDs, F. C. (1979). Candida and Candidosis. Baltimore: University Park Press.

PANEK, A. (1962). Function of trehalose in baker's yeast (Saccharomyces cerevisiae). Archives of Biochemistry and Biophysics 100, 422-425.

Paz, E., Cochrane, J. C. \& Cochrane, V. W. (1984). Spore germination and carbon metabolism in Fusarium solani. VI. Ethanol metabolism and the biosynthesis of amino acids. Experimental Mycology 8, 112.

Pollack, J. H. \& Hashimoto, T. (1984). Ethanol contamination in commercial buffers: ethanol contaminating tris-maleate and other commercial buffers induces germ tube formation in Candida albicans. Applied and Entironmental Microbiology 48, 1051-1052. 
Ram, S. P., Romana, L. K., Shepherd, M. G. \& Sullivan, P. A. (1984). Exo-(1-3)- $\beta$-glucanase, autolysin and trehalase activities during yeast growth and germ-tube formation in Candida albicans. Journal of General Microbiology 130, 1227-1236.

RAMBECK, W. \& Simon, H. (1972). Decrease of glycogen and trehalose in yeast during starvation and during ethanol formation under the influence of propanol or ethanol. Hoppe-Seyler's Zeitschrift für physiologische Chemie 353, 1107-1110.

Reynier, M. (1969). Pyrazole inhibition and kinetic studies of ethanol and retinol oxidation catalyzed by rat liver alcohol dehydrogenase. Acta chemica scandinavica 23, 1119-1129.

Reynouard, F., Lacroix, J., Lacroix, R. \& COMbesCOT, C. (1979). Influence de certains alcools sur la filamentation du Candida albicans en culture. Annales pharmaceutiques françaises 37, 213-216.

RüCHEL, R. (1984). A variety of Candida proteinases and their possible targets of proteolytic attack in the host. Zentralblatt für Bakteriologie, Mikrobiologie und Hygiene, Series A 257, 266-274.

Samaranayake, L. P., Hughes, A. \& MacFarlane, T. W. (1984). The proteolytic potential of Candida albicans in human saliva supplemented with glucose. Journal of Medical Microbiology 17, 13-22.

Sevilla, M. J., Landajuela, L. \& Uruburu, F. (1983). The effect of alcohols on the morphology of Aureobasidium pullulans. Current Microbiology 9, 169-172.

Shepherd, M. G. \& Sullivan, P. A. (1976). The production and growth characteristics of yeast and mycelial forms of Candida albicans in continuous culture. Journal of General Microbiology 93, 361-370.

Shepherd, M. G. \& Sullivan, P. A. (1983). Candida albicans germ-tube formation with immobilized Glc NAc. FEMS Microbiology Letters 17, 167-170.
Simonetti, N., Strippoli, V. \& Cassone, A. (1974). Yeast-mycelial conversion induced by $N$-acetyl-Dglucosamine in Candida albicans. Nature, London 250, 344-346.

Soll, D. R. \& Herman, M. A. (1983). Growth and the inducibility of mycelium formation in Candida albicans: a single-cell analysis using a perfusion chamber. Journal of General Microbiology 129, 2809 2824.

Stewart, P. R. \& Rodgers, P. J. (1983). Fungal dimorphism. In Fungal Differentiation, a Contemporary Synthesis, pp. 267-313. Edited by J. E. Smith. New York: Marcel Dekker

Sullivan, P. A. \& Shepherd, M. G. (1982). Gratuitous induction by $N$-acetylmannosamine of germ tube formation and enzymes for $\mathrm{N}$-acetylglucosamine utilization in Candida albicans. Journal of Bacteriology 151, 1118-1122.

Sullivan, P. A., Chiew, Y. Y., Molloy, C., TempleTON, M. D. \& SHEPHERD, M. G. (1983). An analysis of the metabolism and cell wall composition of Candida albicans during germ-tube formation. Canadian Journal of Microbiology 29, 1514-1525.

Sullivan, P. A., MCHugh, N. J., Romana, L. K. \& SHEPHERD, M. G. (1984). The secretion of $\mathrm{N}$ acetylglucosaminidase during germ-tube formation in Candida albicans. Journal of General Microbiology 130, 2213-2218.

Tani, Y., Yamada, Y. \& Kamihara, T. (1979). Morphological change in Candida tropicalis pK 233 caused by ethanol and its prevention by myoinositol. Biochemical and Biophysical Research Communications 91, 351-355.

WEINHOLD, A. R. (1963). Rhizomorph production by Armillaria mellea induced by ethanol and related compounds. Science 142, 1065-1066. 